\title{
Effect of Probiotics, Garlic and Neem Leaf Powder Supplementation on Feed Efficiency in Caged Broiler
}

\author{
Mohamed K. Abujradah*, Neeraj and Ramesh Pandey \\ Department of Animal Husbandry and Dairying, Sam Higginbottom Institute of Agriculture, \\ Technology \& Science, Allahabad, India \\ *Corresponding author
}

\section{A B S T R A C T}

\begin{tabular}{|l|}
\hline K e y w o r d s \\
$\begin{array}{l}\text { Probiotics, Garlic and } \\
\text { neem leaf powder, Feed } \\
\text { intake, and FCR }\end{array}$ \\
\hline Article Info \\
\hline $\begin{array}{l}\text { Accepted: } \\
\text { 02 May 2018 } \\
\text { Available Online: } \\
\text { 10 June } 2018\end{array}$ \\
\hline
\end{tabular}

An experiment which lasted for 84 days was carried out to investigate the growth performance, haematological and serum biochemical response of caged broiler to probiotics, garlic and neem leaf powder. Eighty day-old commercial broiler chickens were used for the experiment. There were six treatments including control, 4 sub groups with 3 chicks in each to serve as replications with variable proportions of (basal diet + probiotic @ $1 \mathrm{~kg}$ per ton of feed, basal diet + garlic @ $1 \mathrm{~kg}$ per ton of feed, basal diet + neem leaf @ $1 \mathrm{~kg}$ per ton feed, basal diet + probiotic + garlic @ $1 \mathrm{~kg}$ per ton of feed, basal diet + probiotic + neem leaf @ $1 \mathrm{~kg}$ per ton of feed and basal diet + probiotic + garlic + neem leaf @ $1 \mathrm{~kg}$ per ton of feed). Combined supplements T6 basal diet + probiotic + garlic + neem leaf @ $1 \mathrm{~kg}$ per ton of feed gave the best performance $(\mathrm{p}<0.05)$ in all growth performance traits - final body weight, weekly weight gain, weekly feed intake and feed conversion ratio and T0 the least. Administration of probiotics, garlic and neem leaf powder to broiler chickens increased their performance, boosted their immunity as well as improved their general well-being. It is, thus, recommended in broiler chicken production.

\section{Introduction}

India being in tropical region of the world, the prevailing macro climatic conditions is mostly congenial to poultry production. Among the many subsectors of agriculture, livestock sector is gaining momentum in India and within the livestock sector, poultry occupies premium position. The contribution of livestock sectors to the country's GDP is $\$ 47.33$ billion. The value of output from poultry sector is $\$ 8.26$ billion during 2010-11. The organized sector of poultry industry is contributing $70 \%$ of its total output. India ranked $4^{\text {th }}$ largest meat producer in the world and producing about 2.337 million tones of chicken meat annually. Poultry industry in India is growing at the rate of 8 to 15 per cent annum. The per capita availability of poultry meat is $2.15 \mathrm{~kg}$ as against the recommendation of the National Institute of Nutrition at $11 \mathrm{~kg}$ of meat per annum (Prabakaran, 2012).

However, nowadays, the poultry industry has focused more attention towards addressing public concern for environmental and food safety. Animal including poultry are vulnerable to potentially pathogenic 
microorganisms such as Escherichia oil, Salmonella spp., Clostridium perfringens and Campylobacter sputorum. Pathogenic microbial flora in the small intestine compete with the host for nutrients and also reduce the digestion of fat an fat-soluble vitamins due to deconjugating effects of bile acids (Engberg et al., 2000). This leads to depressed growth performance and to increased incidence of disease. Certain feed additives incorporated in poultry feed can create favorable condition in the intestine for the efficient digestion of feed. These feed additives are the biotechnological tools that play very important role in modifying the feed,

Safe broiler meat production always requires maintaining good health, reducing disease outbreak and improving immunity of broilers, because the first growing broilers are mostly susceptible to invasion of pathogenic microorganisms. Antibiotics are known as health care miracle. They are widely used in veterinary field for reducing the incidence of disease caused by microorganisms.

The routine uses of low-doses or subtherapeutic-levels of antibiotics often referred to as Antibiotic Growth Promoter (AGP) in broiler feed have been a common practice for more than 50 years to prevent potential disease as well as to robust gut health, increase meat yield and improve feed efficiency of broilers (Gaskins et al., 2002).

However, a large number of studies have provided clear evidence that haphazard use of AGP in broiler feed throughout the production cycle contributes to the accumulation of antibiotic residues in edible meat entering the human food chain, thereby hastening the emergence of antibiotic-resistant bacteria, which poses a dire risk to consumer health (e.g. erosion of the effectiveness of life-saving drugs, persistence of infections and treatment failure) (Nisha, 2008 and Jallailudeen, 2015).
In response to consumer concerns about the safety and ethics of poultry production, the European Union has banned the use of antibiotics in animal production since 2006. Other developed countries have also limited the antibiotics use in poultry production and most of the feed industries in the developed countries removed all types of antibiotics from poultry feeds and launched the antibiotic-free labeled feed (Cogliani, 2011 and Tavernise, 2013). However, the scenario of indiscriminate practice of AGP in poultry feed is still existing in developing countries.

It has therefore become a crying need of the time to immediate stop haphazard practicing AGP and start searching for cost-effective and health-promoting alternatives to antibiotics. In the recent years, there has been an increasing trend towards using safe, nontoxic and residue free herbal feed additives (HFA) as potential alternative to AGP.

Probiotics are specific chemical agents produced by microorganism containing Lactobacillus acidophilus, Lactobacillus casi, Bifidobacterium bifidum, Aspergillus oryazae and Torulopsis (Mohna et al., 1996).

Garlic (Allium sativum) is considered as a plant with antibiotic, anticancer, antioxidant, immunomodulatory anti-inflammatory, hypoglycemic and cardiovascular- protecting effects (Reuter et al., 1996).

Garlic and neem leaf powder are used as an alternative to those antibiotics. Several studies have shown that inclusion of HFA in broiler diet improves performance, enhances feed utilization and promotes gut health of broiler without having any residual effect on edible meat (Hashemi and Davoodi, 2010).

Neem leaves (Azadirachta indica) and its constituents have been demonstrated to exhibit immunomodulatory, anti-inflammatory, 
antihyperglycemia, antifungal, antiviral, antioxidant, properties (Subapriya and Nagini, 2005).

\section{Materials and Methods}

The experiment was carried out crop research farm at Department of Animal Husbandry and Dairying Sam Higginbottom Institute of Agriculture, Technology and Science, Allahabad, India, during year 2016-2017. The experimental technical programme with Commercial Broilers., 5 weeks of study, no. of treatments: 07 , no. of birds: 84 , no. of replications per treatment: 4 and no. of birds in each replication: 3. The data on various parameters viz, body weight of day old chicks, weekly body weight, gain in weight, weekly feed consumption and feed efficiency was given as per treatment as basal application.

\section{Experimental design}

A total of 84 day old broiler chicks of same hatch will be procured and will be randomly divided into 7 groups as per following dietary regimens:

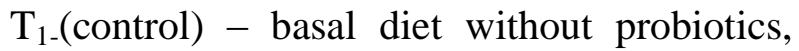
garlic and neem leaf powder.

$\mathrm{T}_{2}$-basal diet + probiotic @ $1 \mathrm{~kg}$ per ton of feed.

T3- basal diet + garlic @ $1 \mathrm{~kg}$ per ton of feed.

T4- basal diet + neem leaf @ $1 \mathrm{~kg}$ per ton feed.

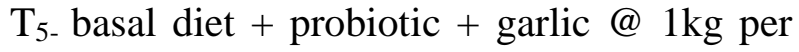
ton of feed.

$\mathrm{T}_{6-}$ basal diet + probiotic + neem leaf @ $1 \mathrm{~kg}$ per ton of feed.

$\mathrm{T}_{7 \text { - }}$ basal diet + probiotic + garlic + neem leaf @ $1 \mathrm{~kg}$ per ton of feed.

\section{Results and Discussion}

\section{Feed intake (g)}

The data regarding feed intake of the chicks randomly distributed into control $\left(\mathrm{T}_{0}\right)$ and seven different treatments $\left(T_{0}, T_{1}, T_{2}, T_{3}, T_{4}\right.$ $\mathrm{T}_{5}$ and $\mathrm{T}_{6}$ ) are presented in the $\mathrm{w} 1$. From the perusal of data on weekly feed intake of broilers, contained in Table 1, it may be noted that feed intake of broilers, irrespective of treatments at one, two, three, four and five weeks of age was d115.83, 428.78, 574.46, 604.49 and $900.21 \mathrm{~g}$, respectively. And the differences in these were significant, indicating thereby a significant effect of age on the feed intake of broilers in all treatments. The results were expected, because under normal phenomenon. The increase in feed intake with increased age, is what are world expected with increase of age. When treatment were feed intake was recorded, the mean highest feed intake was significant in broilers of $\mathrm{T}_{0}(564.54 \mathrm{~g})$, followed by $\mathrm{T}_{1}(546.61 \mathrm{~g}), \mathrm{T}_{4}$ $(528.89 \mathrm{~g}), \mathrm{T}_{2}(516.88 \mathrm{~g}), \mathrm{T}_{3}(516.16 \mathrm{~g}), \mathrm{T}_{5}$ $(502.85 \mathrm{~g})$ and $\mathrm{T}_{6}(497.35 \mathrm{~g})$. And the differences in this volume were found significant.

This indicate that supplementation of probiotics, garlic and neem leaf powder did not influence the feed intake of broilers. However feed intake was recorded higher in treatment groups compared to control. Results showed that supplementation of probiotics, garlic and neem leaf in ration caused significant increase in growth in higher body growth. Similar findings with respect to improvement in body weight gain were observed by earlier researchers (Zanu et al., 2011 and Adeyemo et al., 2013). The improvement in weight gain might be due to anti-protozoal and immunostimulatory properties of neem leave that help to reduce the microbial load and improved the performance (Wankar et al., 2009). 
Ingredient and nutrient composition (\%) of experimental diets (on dry matter basis)

\begin{tabular}{|l|c|c|}
\hline \multicolumn{1}{|c|}{ Ingredients } & Broiler starter $\mathbf{( 0 - 2 1}$ days) & Broiler finisher $\mathbf{( 2 2}-\mathbf{3 5}$ days) \\
\hline Maize & 60.00 & 63.00 \\
\hline Ground nut cake & 23.14 & 18.00 \\
\hline Fish meal & 12.50 & 14.67 \\
\hline Premix (Vitamin) & 2.50 & 2.50 \\
\hline Trace minerals & 0.125 & 0.125 \\
\hline Common salt & 0.30 & 0.30 \\
\hline Methionine & 0.10 & 0.09 \\
\hline Lysine & 0.10 & 0.09 \\
\hline D.C.P & 1.20 & 1.20 \\
\hline Lincomycin & 0.004 & 0.004 \\
\hline Diclazuril (CMP - 200) & 0.020 & 0.020 \\
\hline Nutrient composition & 100 & 100 \\
\hline Moisture (\%) & & \\
\hline Crude protein (\%) & 6.29 & 6.22 \\
\hline Total ash (\%) & 23.29 & 21.28 \\
\hline Cruds protein & 8.02 & 9.34 \\
\hline ME (Kcal/kg) & 22 & 19 \\
\hline
\end{tabular}

Table.1 Average weekly mean feed intake of broiler chicks (g) of different treatments

\begin{tabular}{|c|c|c|c|c|c|c|c|c|}
\hline Week & \multicolumn{7}{|c|}{ Treatments } & Mean \\
\hline & T0 & T1 & T2 & T3 & T4 & T5 & T6 & \\
\hline W1 & 143.29 & 131.29 & 109.76 & 111.35 & 118.00 & 99.35 & 97.76 & $115.83^{*}$ \\
\hline W2 & 462.29 & 450.29 & 422.70 & 424.18 & 426.67 & 414.67 & 400.70 & $428.78^{*}$ \\
\hline W3 & 605.54 & 593.54 & 565.95 & 574.43 & 569.92 & 557.92 & 553.95 & $574.46^{*}$ \\
\hline W4 & 644.29 & 626.29 & 593.70 & 597.67 & 602.18 & 585.67 & 581.65 & $604.49^{*}$ \\
\hline W5 & 967.29 & 931.67 & 892.29 & 873.18 & 927.70 & 856.67 & 852.66 & $900.21^{*}$ \\
\hline Mean & 564.54 & 546.61 & 516.88 & 516.16 & 528.89 & 502.85 & 497.35 & \\
\hline
\end{tabular}

*=Significant

Table.2 Average weekly mean (FCR) or feed efficiency per broiler in different treatments

\begin{tabular}{|c|c|c|c|c|c|c|c|c|}
\hline Week & \multicolumn{7}{|c|}{ Treatments } & Mean \\
\hline & T0 & T1 & T2 & T3 & T4 & T5 & T6 & \\
\hline W1 & 1.70 & 1.56 & 1.22 & 1.27 & 1.29 & 1.10 & 1.00 & $1.31^{*}$ \\
\hline W2 & 1.96 & 1.75 & 1.66 & 1.57 & 1.70 & 1.51 & 1.45 & $1.66^{*}$ \\
\hline W3 & 1.80 & 1.84 & 1.67 & 1.69 & 1.57 & 1.57 & 1.61 & $1.68^{*}$ \\
\hline W4 & 1.88 & 1.86 & 1.54 & 1.61 & 1.86 & 1.62 & 1.45 & $1.69^{*}$ \\
\hline W5 & 2.33 & 2.20 & 2.12 & 2.09 & 1.83 & 1.73 & 1.71 & $2.00^{*}$ \\
\hline Mean & 1.94 & 1.84 & 1.64 & 1.65 & 1.65 & 1.51 & 1.44 & \\
\hline
\end{tabular}

*=Significant 
In the contrary to our findings, there is also some reports in which birds exhibited poor performance and lower body weights in all treatment groups (Deore et al., 2005). While some earlier reports showed no significant variations in weight gain of broilers (Nidaullah et al., 2010; Nnenna and Okey,. 2013).

\section{FCR (g)}

The data regarding the feed conversion ratio of chicks randomly distributed into control $\left(\mathrm{T}_{0}\right)$ and seven different treatments $\left(\mathrm{T}_{0}, \mathrm{~T}_{1}\right.$, $\mathrm{T}_{2}, \mathrm{~T}_{3}, \mathrm{~T}_{4} \mathrm{~T}_{5}$ and $\mathrm{T}_{6}$ ) are presented in the Table 2. From the perusal of data on weekly FCR per broiler, contained in Table 2, it may be noted that FCR per broiler, irrespective of treatments at first, second, third, fourth and fifth weeks of age was 1.31, 1.66, 1.68, 1.69 and $2.00 \mathrm{~g}$, respectively, and the differences in these were significant, indicating thereby significant effect of age on the FCR of broilers in all treatments. When treatment wise FCR was recorded highest FCR observed in followed by $\mathrm{T}_{0}(1.94 \mathrm{~g})$, followed by $\mathrm{T}_{1}(1.84 \mathrm{~g}), \mathrm{T}_{3}(1.65 \mathrm{~g}), \mathrm{T}_{4}(1.65 \mathrm{~g}), \mathrm{T}_{2}$ (1.64g), $\mathrm{T}_{5}(1.51 \mathrm{~g})$ and $\mathrm{T}_{6}(1.44 \mathrm{~g})$. However these in accordance with the results on feed on feed intake and gain in weight of broilers. Similar findings with respect to improvement in body weight gain were observed by earlier researchers (Zanu, et al., (2011) and Adeyemo, et al., (2013)). The improvement in weight gain might be due to anti-protozoal and immunostimulatory properties of neem leaves that help to reduce the microbial load and improved the performance (Wankar, et al., (2009)). In the contrary to our findings, there is also some reports in which birds exhibited poor performance and lower body weights in all treatment groups (Deore, et al., (2005)). While some earlier reports showed no significant variations in weight gain of broilers (Nidaullah et al., 2010; Nnenna and Okey, 2013).
It may be concluded that there was a beneficial effect of effect of supplementation of Probiotics, garlic and neem leaf powder in ration of boilers supplementation in diet of broilers on body weight, gain in weight and feed conversion ratio of broilers. For economic point of ration supplemented with basal diet + probiotic + garlic + neem leaf @ $1 \mathrm{~kg}$ per ton of feed was found the best compared to all the treatments.

\section{References}

Adeyemo, G.O. and Akanmu, A.M. (2013). Effects of neem (Azadirachta indica) and Pawpaw (Carica papaya) leaves supplementation on performance and carcass characteristics of broilers. Available from: http://wwwen.engormix.com/MApoultry industry/ nutrition/ articles. Last accessed on 08-12-2013.

Ansari, J., Khan, S.H., ulHaq, A. and Yousaf, M. (2012). Effect of the levels of Azadirachta indica dried leaf meal as phytogenic feed additive on the growth performance and haemato-biochemical parameters in broiler chicks. J. Appl. Anim. Res., 40(4): 336-345.

Deore, U.B., Ingole, R.S., Waghmare, S.P., Pathak, V.P. and Joshi, M.V. (2005). Clinicopathological investigations in broilers given different levels of neem oil supplementation in feed. J. Bombay Vet. Coll., 13(1-2): 110-111.

Engberg, R.M., Hedemann, M.S., Leser, T.D. and Jensen, B.B. 2000. Pathogenic microbial flora compete with the host for nutrients in the small intestine of poultry. Poultry Science, 79: 1311-19.

Gaskins, H.R., Collier. C. T., and Anderson. D.B., 2002. Antibiotics as growth promotants: mode of action. Animal Biotechnology, 13: 29-42.

Hashemi, S.R., and Davoodi, H., 2010. Phytogenics as new class of feed 
additive in poultry industry. Journal of Animal and Veterinary Advances, 9: 2295-2304.

Mohan B., Kadirevel R, Natarajan A, Bhaskaran M. 1996. Effect of probiotic supplementation on growth, nitrogen utilization and serum cholesterol in broilers. British Poultry Science, 37: 395-401.

Nidaullah, H., Durrani, F.R., Ahmad, S., Jan, I.U. and Gul, S. (2010).Aqueous extract from different medicinal plants as anticoccidial, growth promotive and immunostimulant in broilers. J. Agric. Biol. Sci., 5(1): 53-59.

Nnenna, O.P. and Okey, A.A. (2013). Toxicity and nutritional assessment of aqueous Azadirachta indica (neem) leaf extract in broiler chicks. Int. J. Biosci., 3(6): 172-180

Prabhakaran, R. 2012. Proc. XXIX National Symposium of IPSACON 2012 held at PDP, Hyderabad during 5- ${ }^{\text {th }}$ December 20.
Reuter, H.D., Koch, H.P., and Lawson, L.D., 1996. Therapeutic effects and applications of garlic and its preparations. In: Garlic: The science and therapeutic application of Allium sativum L. and Related Species, Koch, H.P. and Lawson, L.D. (Eds.) Williams and Wilkins, Baltimore, M.D., 135-213.

Subapriya R. and Nagini S. (2005). Medicinal properties of neem leaves. Current medicinal chem. Rev. 5(2), p.149-156.

Wankar, A.K., Shirbhate, R.N., Bahiram, K.B., Dhenge, S.A. and Jasutkar, R.A. (2009). Effect of neem leaf powder supplementation on growth in broilers. Vet. World, 2(10): 396-397.

Zanu, H.K., Kagya-Agyemang, J.K., Kwenin, W.K.J., Bonsu, F.R.K., Antwi, E., and Ateni, S. (2011). Physiological response of broiler chickens to neem and akakapenpen decoctions: Performance and carcass characteristics. Int. J. Poult. Sci., 10(9): 730-733.

\section{How to cite this article:}

Mohamed K. Abujradah, Neeraj and Ramesh Pandey. 2018. Effect of Probiotics, Garlic and Neem Leaf Powder Supplementation on Feed Efficiency in Caged Broiler. Int.J.Curr.Microbiol.App.Sci. 7(06): 78-83. doi: https://doi.org/10.20546/ijcmas.2018.706.011 